\title{
Rancang Bangun Sistem Pemantau dan Pengendali Nutrisi Tanaman Hidroponik Berbasis Modul Long Range (LoRa)
}

\author{
Shafira Rana Rafidah ${ }^{1}$, Agus Wagyana ${ }^{2}$ \\ Program Studi Broadband Multimedia, Jurusan Teknik Elektro, Politeknik Negeri Jakarta, \\ Jalan Prof. Dr. G.A. Siwabessy, Kampus UI Depok 16425 \\ shafiraranarafidah@gmail.com
}

\begin{abstract}
Abstrak
Hidroponik merupakan metode pembudidayaan tanaman tertentu menggunakan air sebagai media tanamnya. Pemenuhan dan pemeliharaan tanaman hidroponik relatif tidaklah sulit, namun membutuhkan perhatian yang lebih, seperti pemantauan kondisi larutan yang harus dilakukan secara rutin. Sampai saat ini, pemantauan parameter larutan nutrisi tanaman hidroponik masih banyak dilakukan secara manual. Penelitian ini bertujuan untuk mendapatkan sistem monitoring suhu dan kepekatan larutan di media tanam serta sistem pengendali otomatis penambahan larutan nutrisi tanaman hidroponik. Sistem menggunakan sensor suhu DS18b20 dan sensor kepekatan larutan SEN0244. Sedangkan komunikasi jarak jauh antara user dan unit hidroponik menggunakan modul LoRa RFM95W dengan frekuensi $915 \mathrm{MHz}$. Secara otomatis sistem akan memberikan larutan nutrisi apabila kadar kepekatan larutan sudah mengalami penurunan di bawah $1000 \mathrm{ppm}$. Hasil pengujian pengiriman data pada kondisi LOS mendapatkan jarak jangkauan terjauh adalah $700 \mathrm{~m}$ dengan RSSI -103 dBm sedangkan pada kondisi NLOS didapatkan jarak terjauh hanya $200 \mathrm{~m}$ dengan RSSI $-101 \mathrm{dBm}$. Selain itu hasil pengujian kondisi kepekatan air selama dua minggu menunjukan bahwa saat sensor kepekatan nutrisi mendeteksi nilai di bawah 1000 ppm maka pompa bekerja memberikan larutan tambahan.
\end{abstract}

Kata kunci: Hidroponik, LoRa, Nutrisi tanaman, Sensor kepekatan, Sensor suhu

\begin{abstract}
Hydroponics is a method of cultivating certain plants using water as a growing medium. The fulfillment and maintenance of hydroponic plants is relatively not difficult, but requires more attention, such as monitoring the condition of the solution which must be done regularly. Until now, the monitoring of hydroponic plant nutrient solution parameters is still mostly done manually. This study aims to obtain a monitoring system for temperature and solution concentration in the growing media as well as an automatic control system for the addition of hydroponic plant nutrient solutions. The system uses a DS18b20 temperature sensor and a SEN0244 solution density sensor. Meanwhile, long-distance communication between the user and the hydroponic unit uses the LoRa RFM95W module with a frequency of $915 \mathrm{MHz}$. The system will automatically provide a nutrient solution if the concentration of the solution has decreased below 1000 ppm. The test results of sending data in LOS conditions get the farthest distance range is $700 \mathrm{~m}$ with RSSI -103 dBm while in NLOS conditions the farthest distance is obtained only $200 \mathrm{~m}$ with RSSI -101 dBm. In addition, the results of testing the water density condition for two weeks show that when the nutrient density sensor detects a value below 1000 ppm, the pump works to provide additional solution.
\end{abstract}

Keywords: Density sensor, Hydrophonics, LoRa, Plant nutrition, Temperature sensor

\section{Pendahuluan}

Penduduk Indonesia memiliki tingkat konsumsi sayuran yang cukup tinggi, hal ini dibuktikan berdasarkan hasil survei yang dilakukan oleh BPS
(Badan Pusat Statistik) pada tahun 2016 yaitu sebesar 97,29\%. Tingkat pemenuhan kuantitas dan kualitas sayuran di Indonesia didukung oleh perkembangan 
teknologi, seperti banyaknya teknik bercocok tanam yang lebih praktis, efisien, sederhana dan produktif dibandingkan teknik konvensional yang biasa digunakan. Salah satu teknik yang sedang digemari dan banyak digunakan oleh masyarakat saat ini yaitu teknik menanam dengan memanfaatkan air atau yang biasa disebut dengan hidroponik. Pembudidayaan dengan teknik hidroponik ini bukan hanya sebagai pemenuhan konsumsi pribadi saja melainkan sebagai salah satu lahan bisnis yang cukup menguntungkan. Sistem hidroponik menekankan pada pemenuhan nutrisi tanaman melalui akar yang menyerap air nutrisi. Elemen yang perlu diperhatikan dalam membudidayakan hidroponik diantaranya jumlah oksigen yang terlarut, tingkat konsentrasi unsur hara yang terlarut (EC), cahaya matahari, tingkat keasaman larutan air (PH) serta suhu [1]. Pemantauan semua elemen ini harus dilakukan secara berkala dan rutin untuk memastikan tanaman mendapatkan nutrisi yang tepat.

Penelitian ini berupaya untuk menerapkan perkembangan teknologi yang semakin maju pada bidang pertanian, khususnya hidroponik. Teknologi yang sedang berkembang dan banyak digunakan saat ini adalah teknologi wireless dengan daya konsumsi yang rendah. Salah satu contoh teknologi tersebut adalah LoRa (Long Range). LoRa adalah teknologi wireless yang menawarkan daya jangkau yang jauh dengan konsumsi yang rendah. LoRa dapat menjangkau jarak hingga $2 \mathrm{~km}[2]$.

\section{Metode Penelitian}

Rancangan sistem terdiri atas dua bagian, yaitu pemantau dan pengendali otomatis larutan tanaman hidroponik. Bagian utama dari pemantau adalah LoRa transmitter dan LoRa receiver. Sensor yang digunakan adalah sensor suhu tipe DS18b20 [3] dan sensor kepekatan larutan tipe SEN0244. Kedua sensor ini dimasukkan ke dalam bak air nutrisi tanaman hidroponik untuk mengukur kondisi air tersebut. Hasil pengukuran dari sensor akan diproses dan dikirim menggunakan modul LoRa transmitter. Frekuensi yang digunakan adalah $915 \mathrm{MHz}$ dengan komunikasi point to point. Diagram blok sistem diperlihatkan pada Gambar 1.

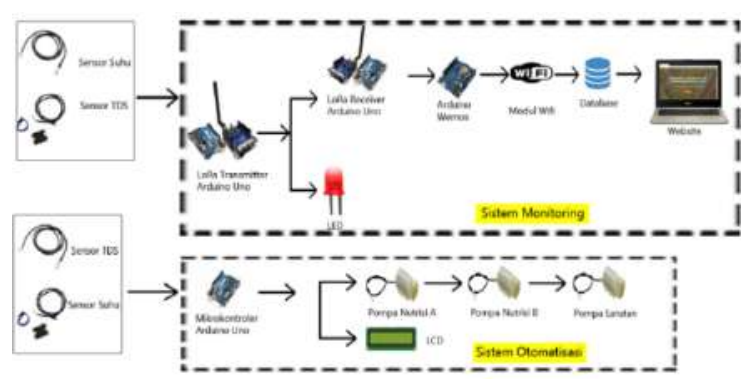

Gambar 1. Diagram blok sistem pemantau dan pengendali hidroponik
Pada LoRa receiver data yang telah diterima selanjutnya data akan dikirimkan ke website dengan menggunakan jaringan internet melalui Wemos D1. Data yang dikirimkan dari Wemos D1 akan diterima di database secara realtime. Data yang tersimpan di database selanjutnya akan ditampilkan pada halaman website yang telah dibuat.

Bagian pengendali terdiri atas dua sensor yaitu sensor suhu DS18b20 dan sensor kepekatan larutan SEN0244 yang dimasukkan ke dalam bak air nutrisi tanaman hidroponik, selanjutnya LCD akan menampilkan nilai kepekatan nutrisi dan suhu air. Sensor kepekatan larutan akan membaca nilai kepekatan air nutrisi dan akan mengaktifkan pompa ketika nilai kepekatan di bawah standar. Visualisasi sistem hidroponik serta alat pemantau dan pengendalinya diperlihatkan pada Gambar 2.

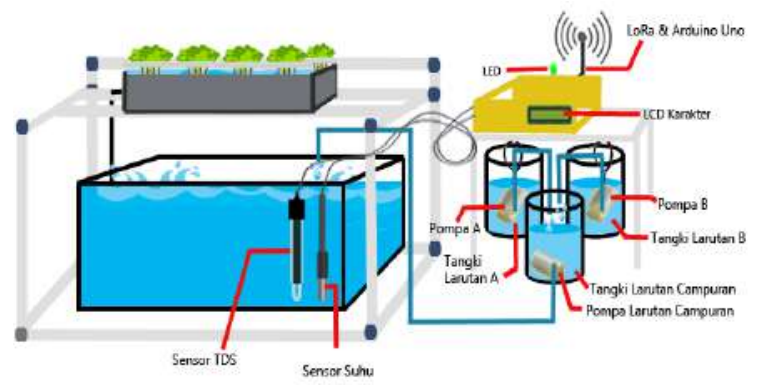

Gambar 2. Visualisasi sistem hidroponik

Langkah-langkah rancang bangun sistem ini terdiri atas studi literatur, perancangan sistem pemantau dan pengendali otomatis, pembuatan visualisasi sistem yang akan dibangun, pengujian dan evaluasi sistem.

\section{Hasil dan Pembahasan}

Gambar 3 memperlihatkan sistem pemantau dan pengendali tanaman hidroponik yang sudah dibuat.

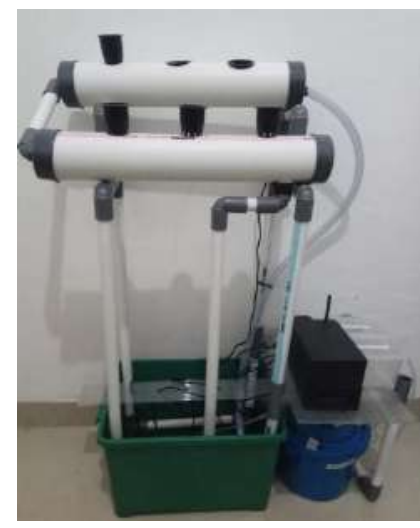

Gambar 3. Sistem pemantau dan pengendali hidroponik yang sudah jadi 


\section{A. Pengujian Sensitivitas Komponen}

Pengujian ini akan membuktikan ketepatan dan keakuratan dari masing-masing komponen yang membangun sistem ini apakah dapat bekerja dengan baik dan dapat memenuhi tujuan penelitian. Pengujian akan dilakukan terhadap beberapa komponen diantaranya sensor suhu DS18b20 dan sensor kepekatan larutan SEN0244, modul LoRa, pompa air, database, dan website

Tabel 1 memperlihatkan hasil pengujian sensitivitas sensor DS18b20.

Tabel 1. Hasil pengukuran sensitivitas sensor suhu DS18b20

\begin{tabular}{|c|c|c|c|c|c|c|c|}
\hline \multirow[t]{2}{*}{ No } & \multirow[t]{2}{*}{ Sampel Air } & \multirow{2}{*}{$\begin{array}{c}\text { Termo } \\
\text { meter } \\
\left({ }^{\circ} \mathrm{C}\right)\end{array}$} & \multicolumn{2}{|c|}{$\begin{array}{l}\text { Sensor Suhu } \\
\text { DS18b20 ( } \mathrm{C} \text { ) }\end{array}$} & \multicolumn{2}{|c|}{$\begin{array}{c}\text { Error Rate } \\
(\%)\end{array}$} & \multirow{2}{*}{$\begin{array}{c}\text { Rata- } \\
\text { rata } \\
\text { Alkur } \\
\text { asi } \\
\text { (\%) }\end{array}$} \\
\hline & & & Sensor 1 & Sensor 2 & Sensor 1 & Sensor 2 & \\
\hline 1 & $\begin{array}{l}\text { Nutrisi } \\
\text { Hidroponik }\end{array}$ & 27,3 & 27 & 27 & 0,0109 & 0,0109 & 99,98 \\
\hline 2 & Sumur & 28 & 27 & 27 & 0,0357 & 0,0357 & 99,96 \\
\hline 3 & $\begin{array}{l}\text { Minum } \\
\text { Dingin }\end{array}$ & 18.8 & 20 & 19 & 0.0638 & 0.0106 & 99.95 \\
\hline 4 & $\begin{array}{l}\text { Minum } \\
\text { Hangat }\end{array}$ & 37.5 & 37 & 38 & 0.0133 & 0.0133 & 99.98 \\
\hline
\end{tabular}

Hasil pengujian menunjukkan nilai sensitivitas dari kedua sensor suhu memiliki nilai rata-rata akurasi yang baik yaitu di atas $99 \%$. Selain itu, nilai rata-rata kesalahan atau error rate dari kedua sensor suhu dengan tipe DS18b20 ini juga memiliki selisih nilai yang kecil dengan pengukuran menggunakan perangkat termometer yang digunakan yaitu di bawah 1. Selisih nilai pengukuran antara sensor suhu dengan termometer juga tidak menunjukkan perbedaan yang sangat signifikan hal ini menunjukkan bahwa kinerja dan keakuratan dari sensor DS18b20 dalam mengukur nilai suhu dari air sangat baik.

Tabel 2 merupakan hasil pengujian sensitivitas sensor DS18b20.

Tabel 2. Hasil pengukuran sensitivitas sensor kepekatan larutan SEN0244

\begin{tabular}{|c|c|c|c|c|c|c|c|}
\hline \multirow[t]{2}{*}{ No } & \multirow[t]{2}{*}{$\begin{array}{c}\text { Sampel } \\
\text { Air }\end{array}$} & \multirow[t]{2}{*}{$\begin{array}{l}\text { TDS } \\
\text { Meter } \\
\text { (ppm) }\end{array}$} & \multicolumn{2}{|c|}{$\begin{array}{c}\text { Sensor } \\
\text { SEN0244 } \\
\text { (ppm) }\end{array}$} & \multicolumn{2}{|c|}{ Error Rate (\%) } & \multirow{2}{*}{$\begin{array}{c}\text { Rata- } \\
\text { rata } \\
\text { Akurasi } \\
(\%)\end{array}$} \\
\hline & & & $\begin{array}{c}\text { Sensor } \\
1\end{array}$ & Sensor 2 & Sensor 1 & Sensor 2 & \\
\hline 1 & $\begin{array}{l}\text { Nutrisi } \\
\text { Hidroponik }\end{array}$ & 765 & 883 & 888 & 0.1542 & 0.1607 & 99.83 \\
\hline 2 & Sumur & 160 & 185 & 172 & 0.1562 & 0.075 & 99.88 \\
\hline 3 & Garam & 914 & 852 & 752 & 0.0678 & 0.1772 & 99.87 \\
\hline 4 & Gula & 131 & 162 & 168 & 0,2366 & 0,2824 & 99,74 \\
\hline 5 & Minum & 47 & 44 & 42 & 0,0638 & 0,1063 & 99,91 \\
\hline
\end{tabular}

Hasil pengujian nilai sensitivitas sensor kepekatan larutan dengan tipe SEN0244 ini memiliki nilai ratarata akurasi yang baik yaitu di atas $99 \%$.

Keseluruhan hasil pengujian menunjukkan pada dua sensor kepekatan larutan ini memiliki nilai pembacaan yang berbeda. Namun perbedaan nilai diantara kedua sensor ini tidak signifikan. Perbedaan hasil pembacaan kedua sensor ini disebabkan adanya perbandingan hasil saat proses kalibrasi. Selain itu, setiap komponen yang dibuat dengan jenis dan tipe yang sama akan memiliki sedikit perbedaan karakteristik dan nilai error antara satu komponen dengan yang lainnya.

Hasil pengujian sensitivitas pompa DC ditampilkan pada Tabel 3.

Tabel 3. Hasil pengujian sensitivitas pompa air

\begin{tabular}{|c|c|c|c|c|c|}
\hline No. & $\begin{array}{c}\text { Sampel } \\
\text { Air }\end{array}$ & $\begin{array}{c}\text { Kepekatan } \\
\text { Larutan } \\
\text { SEN0244 } \\
\text { (ppm) }\end{array}$ & $\begin{array}{c}\text { Pompa } \\
\text { Larutan A }\end{array}$ & $\begin{array}{c}\text { Pompa } \\
\text { Larutan B }\end{array}$ & $\begin{array}{c}\text { Pompa } \\
\text { Campuran } \\
\text { Larutan }\end{array}$ \\
\hline 1 & $\begin{array}{l}\text { Nutrisi } \\
\text { Hidroponik }\end{array}$ & 888 & Altif & Aktif & Aktif \\
\hline 2 & Sumur & 172 & Tidak Aktif & Tidak Aktif & Tidak Aktif \\
\hline 3 & Garam & 752 & Aktif & Aktif & Aktif \\
\hline 4 & Gula & 168 & Tidak Aktif & Tidak Aktif & Tidak Aktif \\
\hline 5 & Minum & 42 & Tidak Aktif & Tidak Aktif & Tidak Aktif \\
\hline
\end{tabular}

Berdasarkan hasil pengujian yang mengacu pada Tabel 3 yaitu pengujian respon tiga pompa air terhadap nilai kepekatan larutan yang dibaca menggunakan sensor kepekatan larutan tipe SEN 2044 menunjukkan nilai sensitivitas komponen bekerja dengan baik. Hal ini dapat terlihat dari data hasil pengujian, ketika nilai kepekatan tidak berada di ambang batas yang ditentukan maka sampel air sumur, sampel air gula dan sampel air minum menunjukkan tidak ada respon yang diberikan pada ketiga pompa air yaitu pompa A, pompa B dan pompa larutan.

Saat sampel air yang diberikan yaitu nutrisi hidroponik dan air garam dengan masing-masing nilai kepekatan larutan yang terbaca adalah 888 ppm dan 752 ppm maka respon dari ketiga pompa bekerja dengan baik sesuai dengan pemrograman yang telah diberikan. Pompa larutan A bekerja selama 2 detik, kemudian pompa A akan mati dan dilanjutkan dengan kinerja dari pompa larutan B selama 2 detik. Setelah pompa larutan B bekerja dan kemudian mati maka akan dilanjutkan oleh pompa larutan yang bekerja selama 3 menit 23 detik. 
Hasil pengujian database ditampilkan pada Gambar 4 berikut ini.

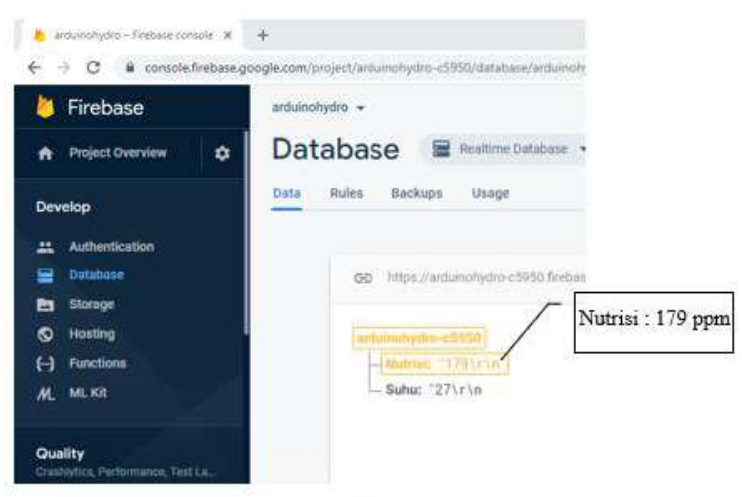

(a) Node Nutrisi

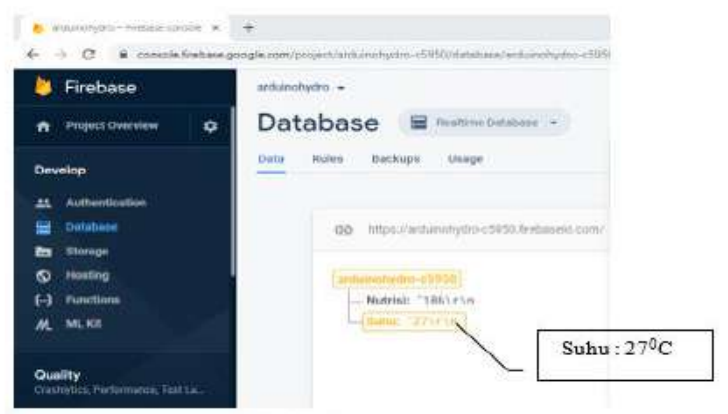

(b) Nodo Suhu

Gambar 4. Hasil pengujian penerimaan data di Database

Proses penerimaan data data yang masuk ditandai dengan dengan indikator pada node-node di database yang akan berubah menjadi warna jingga. Jika node di database berwarna hitam menunjukkan belum adanya data yang masuk atau diterima pada node tersebut. Data yang diterima pada node database akan dilakukan proses sinkronisasi secara terus menerus sehingga data yang sebelumnya diterima akan berubah dengan data yang baru diterima oleh database, dengan begitu database akan bersifat real time.

Sedangkan pada Gambar 5 diperlihatkan hasil pengujian dari tampilan halaman website monitoring saat menampilkan data yang diterima di database.

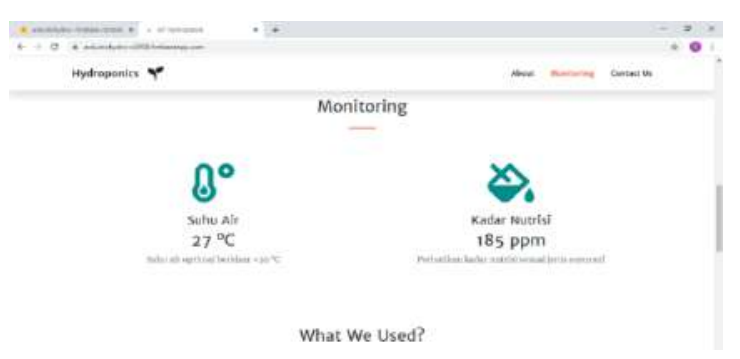

Gambar 5. Hasil pengujian tampilan pada halaman website
Hasil pengujian database dan website berdasarkan dari Gambar 3 dan Gambar 4 menunjukkan bahwa database dan website yang telah dibuat bekerja dengan baik dan mampu menerima, menyimpan, menampilkan serta melakukan sinkronisasi data monitoring larutan nutrisi tanaman hidroponik secara realtime.

\section{B. Pengujian LoRa}

Pengujian ini bertujuan untuk mengukur ketepatan pengiriman data serta daya jangkau dari perangkat LoRa ketika melakukan proses transmisi atau pengiriman data. Pengujian akan terdiri dari jangkauan LoRa, pengujian kekuatan sinyal atau Receive Signal Strength Indicator (RSSI) antara dua perangkat LoRa, serta pengujian pengiriman data dengan kondisi Line of Sight (LOS) dan Non Line of Sight (NLOS). Pengujian akan menggunakan dua perangkat LoRa yang berfungsi sebagai transmitter dan receiver dengan frekuensi yang digunakan adalah $915 \mathrm{MHz}$ dan jenis komunikasi point to point. Berikut ini merupakan hasil pengukuran yang telah dilakukan.

Hasil pengukuran jangkauan LoRa, nilai RSSI dan banyaknya data yang diterima oleh receiver ditunjukkan pada Tabel 4.

Tabel 4. Hasil pengujian LoRa pada kondisi LOS

\begin{tabular}{lcccc}
\hline No. & Jarak (m) & RSSI (dBm) & $\begin{array}{c}\text { RSSI } \\
\text { (mWatt) }\end{array}$ & $\begin{array}{c}\text { Jumlah data } \\
\text { yang } \\
\text { diterima }\end{array}$ \\
\hline 1 & & & & 100 \\
2 & 100 & -67 & $1.995 \times 10^{-7}$ & 100 \\
3 & 150 & -82 & $1,584 \times 10^{-8}$ & 100 \\
4 & 200 & -84 & $3,989 \times 10^{-9}$ & 99 \\
5 & 250 & -86 & $2,511 \times 10^{-9}$ & 98 \\
6 & 300 & -89 & $1,258 \times 10^{-9}$ & 98 \\
7 & 350 & -92 & $6.309 \times 10^{-10}$ & 96 \\
8 & 400 & -95 & $3,162 \times 10^{-10}$ & 95 \\
9 & 450 & -97 & $1,995 \times 10^{-10}$ & 93 \\
10 & 500 & -99 & $1,258 \times 10^{-10}$ & 90 \\
11 & 550 & -99 & $1,258 \times 10^{-10}$ & 89 \\
12 & 600 & -100 & $1 \times 10^{-10}$ & 87 \\
13 & 650 & -102 & $6,309 \times 10^{-11}$ & 85 \\
14 & 700 & -103 & $5,011 \times 10^{-11}$ & 80 \\
\hline
\end{tabular}

Pada penelitian ini jarak maksimal pengujian LoRa dengan kondisi LOS adalah sejauh $700 \mathrm{~m}$. Pada data pengujian yang ditampilkan Tabel 1 di atas bahwa dapat terlihat bahwa semakin jauh jarak dari LoRa receiver dengan LoRa transmitter maka semakin lemah sinyal yang diterima.

Berdasarkan pengujian dan pengukuran yang telah dilakukan dapat terlihat pada setiap jarak pengujian nilai kekuatan sinyal atau RSSI antar kedua perangkat LoRa masih di atas nilai minimum standar dari RSSI yaitu $-120 \mathrm{dBm}$. Selain itu pada setiap jarak pengujiannya, penurunan nilai RSSI tidak 
terlalu signifikan dan banyaknya data yang diterima masih di atas $50 \%$ dari data yang dikirimkan.

Hasil pengukuran dari jangkauan LoRa, nilai RSSI dan banyaknya data yang diterima oleh receiver ditunjukkan pada Tabel 5.

Tabel 5. Hasil pengujian LoRa pada kondisi NLOS

\begin{tabular}{lccccc}
\hline No. Jarak & $\begin{array}{c}\text { Obstacle } \\
(\mathbf{m})\end{array}$ & $\begin{array}{c}\text { RSSI } \\
(\mathbf{d B m})\end{array}$ & $\begin{array}{c}\text { RSSI } \\
(\mathbf{m W a t t})\end{array}$ & $\begin{array}{c}\text { Jumlah } \\
\text { data } \\
\text { yang } \\
\text { diterima }\end{array}$ \\
\hline 1 & 50 & & -88 & $1,584 \times 10^{-9}$ & 38 \\
2 & 100 & & -96 & $2,511 \times 10^{-10}$ & 28 \\
3 & 150 & Beton, & -99 & $1,258 \times 10^{-10}$ & 17 \\
4 & 200 & Kayu, & -101 & $7,943 \times 10^{-11}$ & 15 \\
& & Batu & & & \\
& & Bata, & & & - \\
5 & 250 & Kaca & & & - \\
6 & 300 & & - & & - \\
7 & 350 & & - & & - \\
8 & 400 & & - & & - \\
9 & 450 & & - & & - \\
10 & 500 & & - & & - \\
\hline
\end{tabular}

Seperti yang terlihat pada Tabel 5 di atas bahwa semakin jauh jarak antara LoRa receiver dan LoRa transmitter dengan kondisi banyaknya penghalang di lokasi pengujian karena berada di pemukiman penduduk mengakibatkan penghalang yang ada terdiri dari berbagai jenis material seperti bangunan rumah yang terbuat dari beton, batu bata, pepohonan. Sehingga kondisi ini mengakibatkan semakin melemahnya sinyal yang diterima akibat adanya penyerapan daya atau atenuasi pada masing-masing jenis material penghalang.

Sama halnya dengan kondisi LOS, nilai daya yang diterima receiver akan sebanding dengan semakin jauh jaraknya. Bila jarak semakin menjauhi Lora transmitter maka akan semakin kecil nilai yang didapatkan dan hal ini menunjukkan bahwa sinyal yang diterima semakin lemah. Nilai daya yang semakin kecil ini dapat mengakibatkan berkurangnya kemampuan receiver dalam menerima data yang dikirimkan dan dapat juga mengakibatkan hilangnya data saat proses transmisi.

Dapat dilihat bahwa pada jarak $50 \mathrm{~m}$ dengan kondisi NLOS, daya yang diterima oleh receiver sudah memiliki nilai yang sangat rendah yaitu $1.584 \times 10^{-9}$ milliwatt. Pada jarak 250 hingga 500 meter, LoRa receiver sudah tidak dapat menangkap sinyal akibat daya yang terlalu lemah.

\section{Pengujian Keseluruhan Sistem}

Pengujian ini bertujuan untuk menguji keseluruhan fungsional sistem ketika dioperasionalkan, apakah seluruh komponen yang mendukung dan membangun kedua sistem ini dapat berfungsi dengan baik dan membentuk sistem yang diharapkan sesuai perancangan. Pengujian dilakukan terhadap sistem monitoring dan sistem otomatis pemberian nutrisi dengan menggunakan dua kondisi yaitu pengujian dengan berbagai sampel kondisi air dan pengujian menggunakan rentang waktu selama dua minggu.

Hasil pengujian keseluruhan sistem dengan berbagai sampel air ditampilkan pada Tabel 6 .

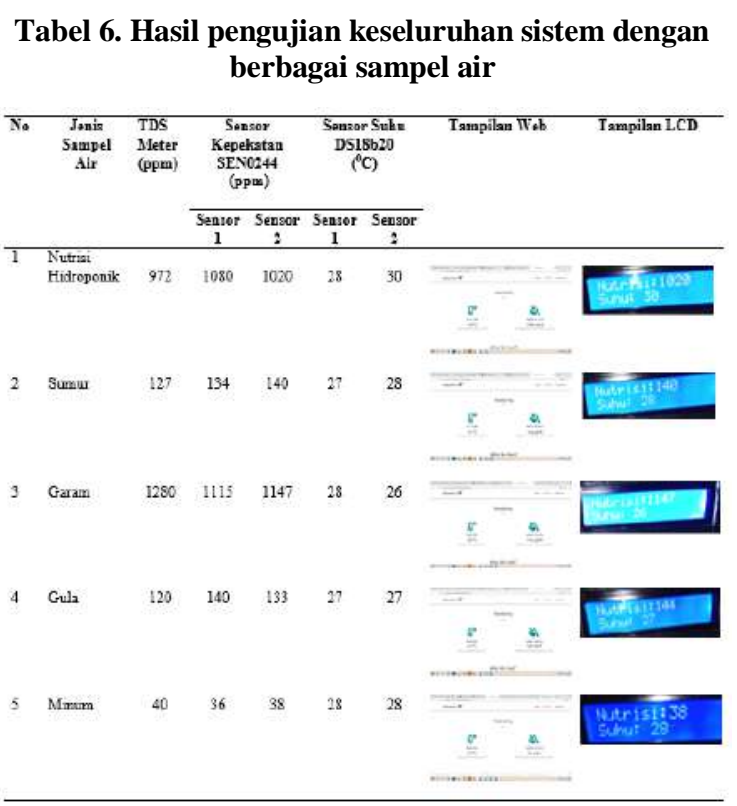

Hasil pengujian menunjukkan bahwa nilai parameter yang ditampilkan pada sistem monitoring di halaman website dan parameter yang ditampilkan di LCD pada sistem otomatis memiliki nilai selisih pengukuran sensor yang tidak signifikan. Selain itu hasil pembacaan sensor dibandingkan dengan pengukuran pada alat TDS meter juga memiliki nilai perbedaan yang tidak signifikan. Sedangkan pada komponen pompa air, ketiga pompa pada sistem otomatis pemberian nutrisi tidak aktif. Hal ini disebabkan karena hasil pengukuran sensor kepekatan terhadap seluruh sampel air menunjukkan nilai yang tidak berada pada ambang batas yang telah ditentukan pada perancangan sistem.

Pada pengujian dalam rentang waktu 2 minggu akan dilihat bagaimana respon dari sistem monitoring dan sistem otomatis pemberian nutrisi tanaman hidroponik.

Hasil pengujian kondisi larutan hidroponik pada minggu ke-1 dapat dilihat pada Tabel 7. 
Tabel 7. Hasil pengujian pada minggu ke-1

\begin{tabular}{|c|c|c|c|c|c|c|c|}
\hline \multirow[t]{2}{*}{$\begin{array}{l}\text { Hari } \\
\text { Ke- }\end{array}$} & \multirow[t]{2}{*}{$\begin{array}{l}\text { Suhu } \\
\text { (C) }\end{array}$} & \multicolumn{2}{|c|}{$\begin{array}{c}\text { Kepekatan Nutrisi } \\
\text { (ppm) }\end{array}$} & \multirow[t]{2}{*}{ LED } & \multirow{2}{*}{$\begin{array}{c}\text { Respon } \\
\text { Pompa } \\
\text { A }\end{array}$} & \multirow{2}{*}{$\begin{array}{c}\text { Respon } \\
\text { Pompa } \\
\text { B }\end{array}$} & \multirow{2}{*}{$\begin{array}{c}\text { Respon } \\
\text { Pompa } \\
\text { Campuran }\end{array}$} \\
\hline & & Monitoring & Otomatis & & & & \\
\hline \multirow[t]{2}{*}{1} & 27 & 1138 & 1120 & Aktif & Tidak & Tidak & Tidak Aktif \\
\hline & & & & & Aktif & Alatif & \\
\hline \multirow[t]{2}{*}{2} & 28 & 1106 & 1091 & Aktif & Tidak & Tidak & Tidak Aktif \\
\hline & & & & & Aktif & Alktif & \\
\hline \multirow[t]{2}{*}{3} & 28 & 1103 & 1078 & Aktif & Tidak & Tidak & Tidak Aktif \\
\hline & & & & & Aktif & Alttif & \\
\hline \multirow[t]{2}{*}{4} & 28 & 1092 & 1085 & Aktif & Tidak & Tidak & Tidak Aktif \\
\hline & & & & & Aktif & Alttif & \\
\hline \multirow[t]{2}{*}{5} & 29 & 1077 & 1069 & Aktif & Tidak & Tidak & Tidak Aktif \\
\hline & & & & & Aktif & Alatif & \\
\hline \multirow[t]{2}{*}{6} & 29 & 1072 & 1064 & Aktif & Tidak & Tidak & Tidak Aktif \\
\hline & & & & & Alttif & Alttif & \\
\hline \multirow[t]{2}{*}{7} & 26 & 1067 & 1060 & Aktif & Tidak & Tidak & Tidak Aktif \\
\hline & & & & & Aktif & Alktif & \\
\hline
\end{tabular}

Sedangkan salah satu untuk tampilan halaman website monitoring yang pada minggu ke-1 ditampilkan pada Gambar 6 berikut ini.

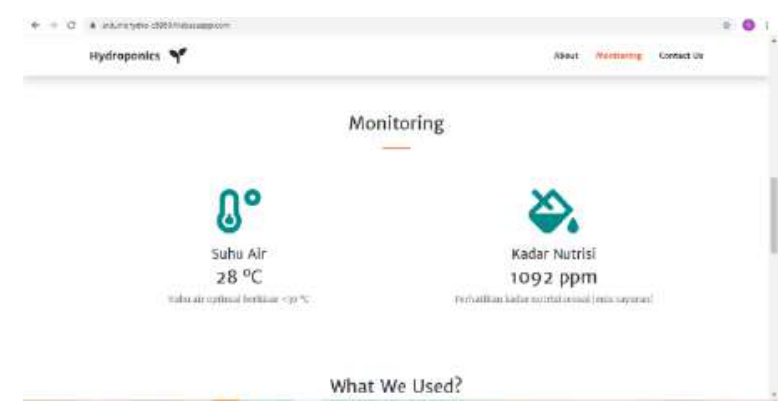

Gambar 6. Hasil pengujian tampilan website minggu ke-1

Hasil pengujian yang didapatkan pada minggu pertama yaitu nilai rata-rata suhu larutan nutrisi berkisar $26^{\circ} \mathrm{C}-29^{\circ} \mathrm{C}$, artinya suhu air nutrisi ini dalam kondisi normal. Sedangkan nilai kadar kepekatan nutrisi untuk larutan hidroponik mengalami penurunan setiap harinya. Namun penurunan kadar nutrisi pada minggu pertama tidak signifikan atau masih di atas standar yaitu 1000 ppm, sehingga masih tergolong dalam kondisi normal. Kondisi kepekatan larutan pada minggu pertama yang masih tergolong normal atau ideal ini mengakibatkan respon dari pompa larutan A, pompa larutan B dan pompa campuran pada minggu pertama tidak aktif. Hal ini sesuai dengan rancangan sistem yaitu mengaktifkan pompa ketika nilai kepekatan dari nutrisi tanaman hidroponik dengan jenis pakcoy $<1000$ ppm.
Sedangkan hasil pengujian kondisi larutan hidroponik pada minggu ke-2 dapat dilihat pada Tabel 8.

Tabel 8. Hasil pengujian pada minggu ke-2

\begin{tabular}{|c|c|c|c|c|c|c|c|}
\hline \multirow[t]{2}{*}{$\begin{array}{l}\text { Hari } \\
\text { Ke- }\end{array}$} & \multirow[t]{2}{*}{$\begin{array}{l}\text { Suhu } \\
\text { (C) }\end{array}$} & \multicolumn{2}{|c|}{$\begin{array}{c}\text { Kepekatan Nutrisi } \\
\text { (ppm) }\end{array}$} & \multirow[t]{2}{*}{ LED } & \multirow{2}{*}{$\begin{array}{c}\text { Respon } \\
\text { Pompa } \\
\text { A }\end{array}$} & \multirow{2}{*}{$\begin{array}{c}\text { Respon } \\
\text { Pompa } \\
\text { B }\end{array}$} & \multirow{2}{*}{$\begin{array}{c}\text { Respon } \\
\text { Pompa } \\
\text { Campuran }\end{array}$} \\
\hline & & Monitoring & Otomatis & & & & \\
\hline \multirow[t]{2}{*}{1} & 27 & 1058 & 1046 & Aktif & Tidak & Tidak & Tidak \\
\hline & & & & & Altif & Aktif & Aktif \\
\hline 2 & 28 & 919 & 876 & Altif & Aktif & Aktif & Aktif \\
\hline \multirow[t]{2}{*}{3} & 26 & 1040 & 1032 & Alktif & Tidak & Tidak & Tidak \\
\hline & & & & & Alktif & Alktif & Alktif \\
\hline \multirow[t]{2}{*}{4} & 26 & 1026 & 1018 & Aktif & Tidak & Tidak & Tidak \\
\hline & & & & & Altif & Altif & Altif \\
\hline 5 & 27 & 981 & 960 & Altif & Altif & Aktif & Aktif \\
\hline \multirow[t]{2}{*}{6} & 28 & 1103 & 1067 & Altif & Tidak & Tidak & Tidak \\
\hline & & & & & Altif & Aktif & Alktif \\
\hline \multirow[t]{2}{*}{7} & 26 & 1078 & 1029 & Altif & Tidak & Tidak & Tidak \\
\hline & & & & & Alttif & Altif & Altif \\
\hline
\end{tabular}

Sedangkan salah satu untuk tampilan halaman website monitoring yang pada minggu ke-2 ditampilkan pada Gambar 7 berikut ini.

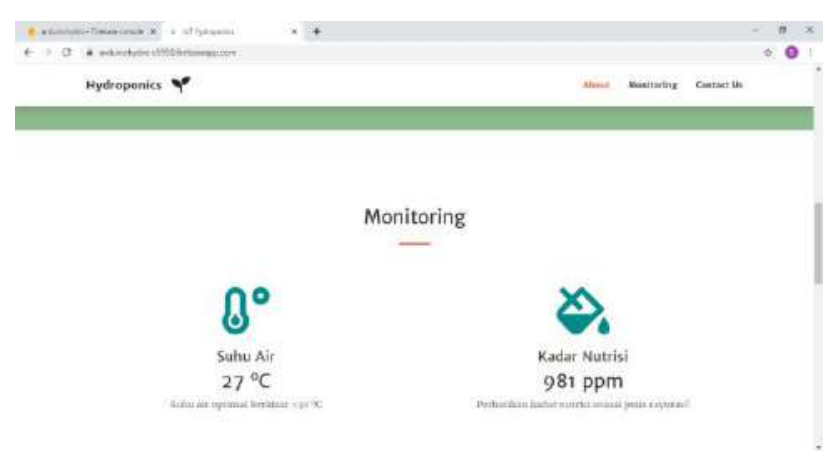

Gambar 7. Hasil pengujian tampilan website minggu ke-2

Hasil pengujian yang didapatkan pada minggu kedua yaitu nilai rata-rata suhu larutan nutrisi berkisar $26^{\circ} \mathrm{C}$ - $28^{\circ} \mathrm{C}$, artinya suhu air nutrisi ini dalam kondisi normal. Sedangkan nilai kadar kepekatan nutrisi untuk larutan hidroponik mengalami penurunan setiap harinya. Pada hari kedua dan hari kelima di minggu pengujian kedua ini dari sejak pemberian larutan nutrisi pertama kali, nilai kepekatan nutrisi mengalami penurunan yang signifikan yaitu berada di bawah ambang batas nilai kepekatan yang ideal atau $<1000 \mathrm{ppm}$. Nilai yang terbaca pada hari kedua ini adalah sebesar 876 ppm sedangkan nilai kepekatan yang terbaca pada hari kelima adalah 960 ppm. Penurunan nilai kepekatan nutrisi ini mengakibatkan respon dari sistem otomatis bekerja. Pompa A bekerja selama 2 detik, kemudian dilanjutkan dengan kinerja dari pompa B bekerja selama 2 detik. Selanjutnya pompa pada campuran 
larutan bekerja selama 3 menit 23 detik. Hal ini menunjukkan bahwa sistem sudah bekerja dengan baik dalam merespon program yang telah diberikan. Berdasarkan hasil pengujian yang dilakukan pada minggu kedua kondisi larutan nutrisi hidroponik menunjukkan bahwa adanya respon yang baik dari sistem otomatis saat nilai kepekatan nutrisi tanaman hidroponik mengalami penurunan akibat penyerapan unsur hara oleh tanaman.

\section{Kesimpulan}

Secara umum sistem ini sudah bekerja dengan baik karena mampu memantau kondisi suhu dan kepekatan media tanam hidroponik melalui modul LoRa dan website serta mampu mengendalikan secara otomatis larutan nutrisi yang diperlukan. Hasil pengujian pengiriman data sensor memperlihatkan bahwa pada kondisi LOS, pemancar LoRa dapat menjangkau penerimanya sampai dengan $700 \mathrm{~m}$ dengan nilai RSSI sebesar $-103 \mathrm{dBm}$. Sedangkan pada kondisi NLOS dapat menjangkau hingga $200 \mathrm{~m}$ dengan nilai RSSI -101 dBm.

\section{Daftar Acuan}

[1] P. Alviani, Bertanam Hidroponik Untuk Pemula, Jurnal Teknologi Rekayasa, 2015

[2] J. W. Wixted, et al., Evolution of LoRa and LoRaWAN For Wireless Sensor Network, Journal of IEEE Sensors, 2016.

[3] Anon., Quick-teck Electronics Components Datasheet. DS18B20 Waterproof Temperature Sensor Cable. 